\title{
Mega-regional trade Agreements: Costly distractions for developing countries?
}

\author{
Badri G. Narayanan ${ }^{1 *}$ and Sangeeta Khorana ${ }^{2}$
}

\author{
*Correspondence: \\ badrig@uw.edu \\ ${ }^{1}$ University of Washington \\ Seattle, 21746 SE 3rd PL, \\ Sammamish, WA 98074, USA \\ Full list of author information \\ is available at the end of the \\ article
}

\begin{abstract}
This paper examines the relationship between mega-regional trade Agreements and diet-related health given that such Agreements aim to liberalize "substantially all trade and investment" that could potentially impact on health through tariff elimination and stronger intellectual property commitments in partner countries. We analyse two interlinked policy concerns: first, how tariff reduction/elimination under mega-regional Agreements impact on the production of sugar? Second, how mega-regional Agreements with Trade-Related Aspects of Intellectual Property Rights (TRIPS)-style and TRIPS-plus commitments modify intellectual property rules among partner countries and impact on developing countries' access to life-saving drugs and medicines? Using a dynamic Global Trade Analysis Project model, we find there are significant health consequences of trade commitments undertaken by developing countries with potential detrimental health effect on populations such that first, higher production of sugar alters consumption trends. Second, despite stricter intellectual property rules, which result in net global gains, developing countries suffer from the regulatory chill effect.
\end{abstract}

Keywords: Government policy (118), Economic integration (F15), Trade policy (F13)

\section{Introduction}

Prior to the Brexit and USA's withdrawal from Trans-Pacific Partnership (TPP), megaregionals were the latest trend in trade Agreements. The best-known examples of mega-regional Agreements are the TPP, the Transatlantic Trade and Investment Partnership (TTIP) between the USA and the European Union (EU), both promoted by the USA, and the Regional Comprehensive Economic Partnership (RCEP) between Australia, China, India, Japan, Korea, New Zealand and ten countries of the Association of Southeast Asian Nations (ASEAN). In particular, TPP and TTIP are classic examples of mega-regional Agreements that seek to introduce innovative content that reflects twenty-first-century trade and economic exchanges such that commitments undertaken on "traditional and new areas of trade" are likely to have far-reaching implications on global trade regulation and public policy. This paper examines how these critical mass Agreements could be employed to bring some of the mega-regionals' new rules and issues into the system? While studies specifically analyse the economic implications of TPP and TTIP on developing countries, no work focuses on how such mega-regional Agreements that aim to liberalize "substantially all trade and investment" can potentially 
impact on global health through commitments on tariff elimination and stronger intellectual property (IP) rules.

This paper identifies how trade commitments, based on the intrinsic characteristics of the provisions or chapters in TPP and TTIP, could interact with and impact on public health in developing countries. This follows from the concerns that the haste of negotiators to conclude deep Agreements could impose ill-conceived constraints on domestic regulators' access to medicines and has wide-ranging implications for public health policies in developing countries by feeding into domestic regulation. We analyse two interlinked policy concerns: firstly, how tariff reduction/elimination under mega-regional Agreements impacts on production of sugar, and by inference higher consumption. A second related policy area examined is the impact of mega-regional commitments, which include Agreement on Trade-Related Aspects of Intellectual Property Rights (TRIPS)-like and TRIPS-plus commitments, on IP protection rules and even modification of such rules by partner countries, thus impacting the access of people in developing countries to life-saving drugs and medicines.

Tariff reduction/elimination on sugar, beverages and sugar products can have direct health implications for populations of partner countries' populations. The health implications stem from the fact that while reductions in barriers to trade increase consumer food choices and improve supply for net-food-importing countries, trade liberalization can lead to disproportionate increase in imports and domestic production of processed foods, skewing the food supply towards an oversupply of highly processed foods that are calorie-rich and nutrient-poor (Clark et al. 2012). Thus, lower/no tariffs and lower prices of these products will lead to higher consumption that is scientifically linked to adverse dental health with possible association with obesity, diabetes and cardiovascular conditions. Similar is the case with higher tobacco consumption that has proven adverse health effects increasing the risk and incidence of oral and lung cancer. It is in the context of such health concerns from increased consumption of these products that require policy-makers in developing countries to carefully analyse health effects of deep "acrossthe-board" commitments (see Clarke 2008; Roffe et al. 2008). In this context, addressing health concerns and devising appropriate public policies to keep a check on burgeoning health expenditure are key, given that trade policy can impact on partner countries' domestic pharmaceutical industries through providing (a) access to medicines and (b) incentives for innovation in the development of new life-saving drugs.

While several studies model the economic effects of trade liberalization, there is limited analysis that examines the health effects of zero tariffs and stronger IP rules from a public health perspective. It is in this context that the link between zero tariffs, on sugar and sugary beverages, and tobacco and tobacco products, is examined by this paper and how these are likely to contribute, on the one hand, to adverse impact on people's health, while stronger IP commitments can pose a policy paradox for policy-makers, on the other. This also addresses a related question whether commitments under mega-regional Agreements that address trade issues and twenty-first-century challenges can be heralded as a truly next-generation regional Agreement.

This paper employs dynamic GTAP (GDyn) model firstly to examine the effects of TPP and TTIP on production, consumption, prices and trade of "harmful" products, i.e. sugar and tobacco, over 2015-2030 and secondly to assess the costs as a result of imposing 
stringent IP rules across the world following commitments under these mega-regional Agreements. The analysis focuses primarily on developing countries. Results indicate that there are significant health consequences of commitments undertaken by developing countries in that firstly, there is notable expansion in the production of sugar (about $0.3 \%$ per year) due to trade liberalization; secondly, while stricter IP rules are likely to lead to net global gains in terms of gross domestic product (GDP), poorer countries suffer implying that even without accounting for the "health justice" argument about allowing access to medicines stricter IP rules are likely to work against the poorer countries.

\section{Related literature}

At the multilateral level, trade in health products and services are governed by the WTO Agreements. The WTO-TRIPS Agreement (Article 8) recognizes the right of WTO members to "adopt measures necessary to protect public health and nutrition and to promote the public interest in sectors of vital importance to their socio-economic and technological development, provided that such measures are consistent with the provisions of the Agreement". It is common knowledge that developing countries have been averse to committing to TRIPS at the multilateral level, mainly on the grounds that the interests of developing countries are comparatively less reliant upon knowledge-based, intellectual property intensive goods and services which makes these countries' consumers and net importers of intellectual property, not producers and net exporters ${ }^{1}$ (Gaisford et al. 2007). The reluctance of developing countries is based on the fact that they have to bear significant costs of adjusting to the TRIPS Agreement, which requires institutional and judicial infrastructure to educate, inform, implement, regulate, manage and enforce IPR protection provisions. Historically, developing countries' joined the TRIPS Agreement with much reluctance with the carrot of greater market access to developed country markets for their agricultural goods and textiles, in combination with the stick of exclusion from the WTO and the General Agreement on Tariffs and Trade (GATT) for the exports of their goods should they not join TRIPS (Kerr 2003, 2007, 2011). Developing countries' incentives to joining the TRIPS have been eroded by the fact that the promised increased trade via greater market access for agricultural goods and textiles has not materialized as developed countries have implemented strategically blocking tactics (Kerr 2005). Of late, TRIPS has impacted on countries' health policy through tariff reduction, as is the case with sugar and tobacco. In addition, patent protection and innovation as well as through the diffusion of new technologies to populations are related issues impacting on developing countries' policy space.

The TRIPS Agreement includes specific rules on compulsory licensing, parallel importation and the application of patent law. For instance, Article 30 allows governments to make limited exceptions to patent rights provided certain conditions are met. The Agreement goes on to recognize that such exceptions must not "unreasonably" conflict with the "normal" exploitation of the patent and must not unreasonably prejudice the legitimate interests of the patent owner, while taking the legitimate interest of

\footnotetext{
${ }^{1}$ The value of a single global IPR standard where all nations strive to that of the USA, for example, is debatable when as Drahos (2003) notes strong patent protection makes sense for the USA, with over 3600 scientists and engineers involved in research and development per million people, but less so for a country such as Rwanda whose ratio of 35 scientists per million clearly illustrates the lesser role IPR plays in its economy.
} 
third parties into account. Article 31 of the Agreement allows developed and developing countries to provide for compulsory licensing in their national legislation and does not limit the reasons for which governments may grant compulsory licences. Having said this, governments' use of a patent without the authorization of the right holder can only be done only under a number of conditions that protect the legitimate interests of patent holders. There have, however, been instances when generic producers and originator companies in developed and developing countries have disagreed on issues of patent linkage and/or the extent of data protection. A prominent case law example extraterritorial application of national laws under TRIPS is European Union-Seizure of Generic Drugs in Transit (WT/DS408, May 2011). Yet another Article 30 interpretation is in case law Canada-Pharmaceuticals (WTO/DS114) that allows countries to allow manufacturers of generic drugs to use the patented invention, without the patent owner's permission and before the patent protection expires, for the purpose of obtaining marketing approval from public health authorities.

At the mega-regional, standards committed are higher than TRIPS, i.e. TRIPS-plus, and are increasingly a norm and common feature. The same applies at the bilateral level and analysis shows that TRIPS-like commitments require partners to commit bilaterally to the protection of IPRs, often far in excess of the minimum standards beyond and what was internationally agreed upon in the TRIPS Agreement. The literature also confirms this growing trend to increasingly include TRIPS-like and even higher commitments, i.e. TRIPS-plus (Vivas-Eugui 2003; Reichenmiller 2005). Such provisions take several forms: first, TRIPS-plus commitments extend the protection on patents, particularly for pharmaceuticals and data, which take the form of wider patent applicability, restricting patent oppositions, and/or extension of the patent durability. In fact, data exclusivity and patent registration are common TRIPS-plus pharmaceutical patent provisions undertaken at a bilateral level. Examples of patent strengthening provisions include the extension of duration patents on agrochemicals and pharmaceutical products from 20 to 25 years and industrial designs from 10 to 15 years, most common in several US RTAs. There are examples of extension of patent duration beyond the TRIPS commitment of 20 years, under the US-Macedonia regional trade Agreement (RTA) where patents on agrochemicals and pharmaceutical products have been increased from 20 to 25 years, and the EU-Morocco RTA where patents on industrial designs were increased from 10 to 15 years. In addition, the USA is also implementing provisions in RTAs that automatically extend patent terms if an extension is granted in a third country (El Said 2010).

Stronger IPR enforcement with penalties for non-compliance or violations is another common feature of bilateral commitments. Further, data exclusivity commitments are increasingly common within bilateral settings. For instance, Roffe et al. (2008) examine the issue of implementation of data exclusivity commitments in Jordan and Guatemala following RTAs with the USA. The study suggests that intellectual property rules reduced access to some generic drugs already on the market and delayed new entry of other generics. Further, TRIPS-plus provisions also limit or undermine developing countries' policy options for legislating and using TRIPS flexibilities, even though safeguards and flexibilities were included in the TRIPS Agreement to enable governments to protect public interests, including access to medicines. This has led to concerns that TRIPS-plus 
provisions in FTAs will undermine public health safeguards and objectives-notably access to medicines, as well as delay generic market entry and competition.

These concerns are particularly pertinent within the context of the TPP Agreement, which has been positioned as a "model" for the twenty-first century implying that similar provisions are likely to appear in future trade Agreements, including those involving developing countries. The analysis of TPP commitments suggests that the Agreement reaffirms participating countries' commitment to the WTO's 2001 Declaration on the TRIPS Agreement and public health. It is interesting to note that the TPP does include a specific chapter with commitments that have implications for the health sector. The TPP Agreement, however, includes specific commitments by partners on pharmaceuticals-related provisions, which relate to the development of innovative medicines and availability of generic medicines, and in fact provides for stronger protection of IP. The IP chapter also includes commitments on the protection of undisclosed tests and other data submitted to obtain marketing approval of a new pharmaceutical or agricultural chemical product. However, no linkage between low tariffs on agricultural products and health linkage has been deliberated upon in the Agreement. Ongoing TTIP talks, between the EU and USA, do not explicitly highlight the link between lower tariffs and implications on health policy from information available in the public domain.

\section{Methods}

In this section, we describe the model, the assumptions underlying the baseline projection for the dynamic simulations and TPP/TTIP policy shocks. We also underline the methodological caveats of the study.

\subsection{Model description}

We implement simulations based on the GTAP dynamic model. GDyn is a multi-sector, multi-region recursive dynamic computable general equilibrium (CGE) model, described in Ianchovichina and McDougall (2001). Detailed information on GDyn database construction and parameterization of the model as well as various applications of GDyn model are available in Ianchovichina and Walmsley (2012).

GDyn model adopts a disequilibrium approach to modelling capital mobility, allowing short- and medium-run differences in the rates of return across regions, implying imperfect capital mobility over the medium term. The dynamics of capital adjustment eliminate these differences in the long run, resulting in long-run perfect capital mobility across regions.

Investment in a given region, allocated by the global trust, depends on two factors: expectations on the rates of return and the global balance between investment and savings. In the model, capital drifts away from regions with lower expected rates of return to those with higher returns. Over time, therefore, the expected rates of return come down, resulting in the equalization of expected and actual net rates of return within and across regions in the long run.

Financial assets (equity interests in physical capital) are incorporated in the model to capture the welfare effects of international capital mobility. In this accounting system, firms own physical capital, but rent land and natural resources from regional households, which also own financial assets laying indirect claims on physical capital. Regional 
households hold equity in firms in all regions through a fictional entity called "global trust" that allocates foreign investment. Thus, their wealth is the sum of their equities in domestic firms and in the global trust. The saving of each regional household is allocated to domestic and foreign investment, on the assumption that the shares of domestic and foreign investments are held constant, subject to adding up constraints to balance regional accounts. The model does not attempt to capture real financial sector dynamics.

GDyn has been shown to be able to realistically capture dynamics in several ways (Ianchovichina et al. 2014). ${ }^{2}$ Furthermore, GDyn model captures the capital mobility due to specific policy shocks, by different channels; firstly, the changes in fundamentals of these economies owing to cost reduction facilitated by trade can help allocate investment more or less in a region depending on the extent to which it has become competitive and investment-friendly; secondly, there are direct shifting levers that can shock the extent of policy facilitation that can encourage investment.

\subsection{Baseline projection}

For the purposes of our study, we run the model on the GTAP 8.1 database, documented in Narayanan et al. (2012), with 2007 as the base year. We work with 22 countries/ regions and 32 sectors, aggregated from 134 countries/regions and 57 sectors available in the GTAP database.

Table 1 sets out the regions/sector aggregations.

We project the database to 2030 drawing on historical data for GDP, population and labour supply for the period to 2015 and on long-run projections from Chappius and Walmsley (2011) for the period to 2030. These long-run projections are derived from Foure et al. (2010), from the projections for 128 countries to 2050, based on a threefactor production function (capital, labour and energy), accounting for the energy constraint through dynamic modelling of energy productivity, and applying a FeldsteinHorioka-type relationship between savings and investment rates.

A baseline assumption is that the supply of factors other than capital and labour is exogenous. Capital supply in the model is determined by the savings-investment module while labour supply, for both skilled and unskilled labours, adjusts to keep the real factor price of labour fixed. In other words, this is a labour-unconstrained baseline, wherein there is unlimited supply of labour to draw from, for economic growth implied by the GDP baseline. Another assumption is that the recently concluded WTO Trade Facilitation Agreement (TFA) is fully implemented by all countries. This assumption is implemented by removing all tariff equivalents of time as a barrier to trade, as estimated by Minor and Hummels (2011), by 2015. This reduces the goods sector Non-Tariff Barriers (NTBs) in the baseline, hence reducing the scope for the TPP/TTIP to boost additional trade.

Table 2 summarizes the baseline assumptions employed. Almost all low-income countries are expected to grow faster in terms of GDP than the developed economies. For instance, India is expected to grow faster in terms of population and labour force. We

\footnotetext{
${ }^{2}$ For example, Walmsley, Hertel and Ianchovichina (2006) accurately anticipated the degree and timing of the tapering off of China's high growth and inflows of foreign direct investment (FDI). This practical validation provides some confidence in the application of the GDyn model for the present purpose, though this particular phenomenon doesn't have a direct bearing to TPP/TTIP features.
} 
Table 1 List of regions and sectors Source: Assumptions by the authors

\begin{tabular}{|c|c|c|c|}
\hline \multicolumn{4}{|c|}{ Regions } \\
\hline 1 & Japan & 12 & India \\
\hline 2 & China & 13 & Australia \\
\hline 3 & Korea & 14 & New Zealand \\
\hline 4 & Taiwan & 15 & USA \\
\hline 5 & Singapore & 16 & Canada \\
\hline 6 & Indonesia & 17 & Mexico \\
\hline 7 & Malaysia & 18 & Chile \\
\hline 8 & Philippines & 19 & Peru \\
\hline 9 & Thailand & 20 & Russia \\
\hline 10 & Vietnam & 21 & EU28 \\
\hline 11 & Rest of ASEAN & 22 & ROW \\
\hline \multicolumn{4}{|c|}{ Sectors } \\
\hline 1 & Rice & 17 & Non-ferrous metals \\
\hline 2 & Other grains & 18 & Metal products \\
\hline 3 & Sugar & 19 & Machinery \\
\hline 4 & Other crops & 20 & Electronic equipment \\
\hline 5 & Livestock & 21 & Motor vehicles \\
\hline 6 & Fossil fuels & 22 & Other transport equipment \\
\hline 7 & Natural resources & 23 & Other manufacturing \\
\hline 8 & Meat & 24 & Construction \\
\hline 9 & Dairy products & 25 & Trade \\
\hline 10 & Other food products & 26 & Sea transport \\
\hline 11 & Textiles & 27 & Air transport \\
\hline 12 & Apparel & 28 & Other transport \\
\hline 13 & Wood and paper & 29 & Communication \\
\hline 14 & Petroleum products & 30 & Financial services \\
\hline 15 & Chemical products & 31 & Other private services \\
\hline 16 & Steel & 32 & Government services \\
\hline
\end{tabular}

note that there is a visible shift towards skilled labour and away from unskilled labour in many countries in the world; this comes from the IIASA baseline for labour force, which takes into account global trend towards improved educational and human capital attainment that would lead to increased availability of skilled labour force.

\subsection{Closures}

Under the GTAP model's default microeconomic closure, factor endowments (i.e. the total supply of labour, both skilled and unskilled, as well as of capital and land) are fixed and factor prices adjust to restore full employment of the factors of production in the post-shock equilibrium. ${ }^{3}$ Alternatively, the return to capital or to labour can be fixed and the supply of capital and/or labour adjusts to restore equilibrium. ${ }^{4}$ In the GDyn model, investment adjusts to changes in the rate of return. In addition, by fixing wage rates, we allow labour supply to adjust to changes in wages. As a result, the TPP/TTIP impacts

\footnotetext{
3 This is sometimes described as reflecting a medium-term time horizon in which labour supply is relatively "sticky".

4 The closure rule in which the rate of return to capital is fixed is sometimes described as reflecting longer-run "steadystate" growth conditions.
} 
Table 2 Baseline projections (2015-2030: Annualized) Source: Calculations by the authors, based on Foure et al. (2010)

\begin{tabular}{lclcl}
\hline & $\begin{array}{l}\text { Population } \\
\text { growth (\%) }\end{array}$ & $\begin{array}{l}\text { GDP } \\
\text { growth (\%) }\end{array}$ & $\begin{array}{l}\text { Unskilled labour } \\
\text { force growth (\%) }\end{array}$ & $\begin{array}{l}\text { Skilled labour } \\
\text { force growth (\%) }\end{array}$ \\
\hline Japan & -0.46 & 1.10 & -1.40 & 0.49 \\
China & 0.31 & 7.30 & -0.33 & 2.26 \\
Korea & 0.00 & 1.68 & -1.09 & 1.76 \\
Taiwan & 0.24 & 4.53 & -0.55 & 1.73 \\
Singapore & 0.51 & 1.91 & -2.67 & 1.94 \\
Indonesia & 0.71 & 5.39 & 0.64 & 3.37 \\
Malaysia & 1.08 & 4.36 & 0.24 & 3.87 \\
Philippines & 1.35 & 4.42 & 1.53 & 3.56 \\
Thailand & 0.33 & 4.80 & -0.78 & 2.48 \\
Vietnam & 0.82 & 4.59 & 0.57 & 3.51 \\
Rest of ASEAN & 0.82 & 4.56 & 0.23 & 4.33 \\
India & 0.92 & 6.80 & 1.09 & 3.68 \\
Australia & 0.85 & 2.02 & -0.11 & 1.51 \\
New Zealand & 0.68 & 2.22 & 0.03 & 1.34 \\
USA & 0.72 & 2.07 & -0.13 & 1.58 \\
Canada & 0.82 & 2.14 & 0.06 & 0.84 \\
Mexico & 0.61 & 3.21 & 0.46 & 2.68 \\
Chile & 0.66 & 2.70 & 0.33 & 2.43 \\
Peru & 0.63 & 2.96 & 0.39 & 2.56 \\
Russia & -0.45 & 2.69 & -1.36 & 0.14 \\
EU28 & 0.03 & 1.44 & -1.55 & 1.03 \\
ROW & 1.35 & 3.88 & 1.44 & 3.51 \\
\hline
\end{tabular}

generate "endowment" effects: that is, the amount of labour and capital in an economy change based on changes in returns to labour and capital. Compared to simulations that adopt the default closure, our simulations show larger impact on quantities and less impact on prices.

As regards GTAP's macroeconomic closures, two approaches are available. First, the current account can be fixed. This assumes that the external balance is determined entirely by domestic investment-savings dynamics. When trade policy shocks result in unbalanced changes in imports and exports, the original trade balance is then restored by implicit exchange rate adjustments. Alternatively, the current account can be allowed to adjust to the trade shock. The choice of macroeconomic closure can also have significant implications for the model outcomes. ${ }^{5}$ We necessarily adopt the closure where the current account adjusts; this reflects the active role of FDI in our model. In other words, due to the flexibility of current account, in order to make sure that net exports and the sum of net savings and net factor income equal each other, investment can move from one country to another, to keep up with the movements in trade. This is also the reason why the tariff and NTB shocks that affect trade can also affect investment.

\footnotetext{
${ }^{5}$ See DeRosa and Gilbert (2004) for a comparison of the impact of using alternative macroeconomic closures in the context of modelling the Korea-US FTA. The fixed current account simulations substantially reduce the economic welfare gains for Korea (to three-fifth the level of the simulation with flexible current account) and marginally (by 5\%) for the USA.
} 


\subsection{Description of policy shocks}

To evaluate the effects of TPP and TTIP, it is necessary to make assumptions about the content of these Agreements and the scale of the resulting policy shocks. The TPP is reportedly essentially locked up but the details are not known; how significant the compromises will turn out to be in terms of the level of ambition remains to be seen. The TTIP has run into relatively strong headwinds over the issue of regulatory convergence and is both on a slower track than TPP and also less certain in terms of how far and through which modalities it will progress.

As our concern is to demarcate the potential scope for spill over, we adopt assumptions that represent relatively ambitious outcomes. The scenarios are thus in the nature of a "thought experiment" rather than a forecast based on the following assumptions. First, all industrial tariffs are removed among the TPP member countries as well as TTIP member countries by 2030, with some exceptions based on the "best guess" scenario propounded by Ciuriak and Jingliang $(2014)^{6}$; for the automotive and textiles and clothing sectors, we assume gradual phase-out of tariffs. For agriculture, we exclude traditionally sensitive sectors, including rice into Japan, sugar into the USA, dairy into Canada. Otherwise we eliminate the protection in the GTAP version 8 database.

Second, for goods NTBs for manufacturing and agricultural sectors, commonly used estimates from Kee et al. (2009) correspond to early 2000 and are outdated at this point. We use NTBs estimated by Hummels and Minor (2009) for "time as a barrier to trade" and reduce them as described above to take account of the WTO TFA in developing the baseline projection. The remaining goods NTBs are reduced slightly under the TPP/ TTIP, to capture the reduction in duplicative conformity assessment arising from mutual recognition within the TPP/TTIP zone. This amount to $0.25 \%$ reduction in the cost of trade for manufactured goods, other than electronic products for which we assume such practical measures have already been exhausted, following Ciuriak and Jingliang (2014).

Third, NTBs in services are reduced. Estimates of the ad valorem tariff equivalents (AVEs) of services NTBs from Wang et al. (2009) and Brown et al. (2010) as implemented by Lee and Itakura (2015) are used. Table 3 provides a summary of the tariff equivalents of NTBs. These AVEs are introduced into the dataset from 2007 to 2012 and then reduced by up to $20 \%$ under the TPP/TTIP, based on an estimate provided by Lee and Itakura (2015).

Fourth, an increase in the real wages of unskilled labour in developing countries across the world as a result of increase in labour standards owing to the TPP/TTIP is an assumption. These increases range from 0 to $20 \%$ (some evidence to this extent has been provided in Narayanan et al. 2016), in an inversely proportionate way to the size of per-capita GDP of the country; in other words, poorer countries would face a higher increase in real wages, since they would incur higher costs in improving their presumably low labour standards. Table 4 shows the extent to which we raise the real unskilled wages in these simulations.

Fifth, a similar schema for environmental standards, based on per-capita income, is adopted. We identify the sectors in terms of emissions intensity, so as to introduce lower

\footnotetext{
${ }^{6}$ This is based on the revealed willingness of the participants to make concessions in FTAs.
} 
Table 3 Average tariff equivalents (ad valorem, \%) of NTBs in services (2015) Source: Adapted by the authors from Wang et al. (2009), Brown et al. (2010) and Lee and Itakura (2015)

\begin{tabular}{lc}
\hline India & 111.70 \\
Australia & 15.38 \\
New Zealand & 10.75 \\
USA & 6.8 \\
Canada & 18.64 \\
Mexico & 50.32 \\
Chile & 22.35 \\
Peru & 43.24 \\
Russia & 65.64 \\
EU28 & 8.56 \\
ROW & 40.52 \\
Others & $\sim 30$ \\
\hline
\end{tabular}

Table 4 Projected percentage increase in costs and productivity from standards compliance (2015-2030)

\begin{tabular}{|c|c|c|c|c|}
\hline & Labour standards** & Environmental standards* & IP rules* & Vintage capital*** \\
\hline Japan & 0 & 0 & 0 & 0 \\
\hline China & 5.75 & 0.58 & 0.86 & 2.3 \\
\hline Korea & 0.74 & 0.07 & 0.11 & 0 \\
\hline Taiwan & 0.93 & 0.09 & 0.14 & 2.3 \\
\hline Singapore & 0.42 & 0.04 & 0.06 & 2.3 \\
\hline Indonesia & 8.36 & 0.84 & 1.25 & 2.3 \\
\hline Malaysia & 2.29 & 0.23 & 0.34 & 2.3 \\
\hline Philippines & 9.9 & 0.99 & 1.48 & 2.3 \\
\hline Thailand & 4.36 & 0.44 & 0.65 & 2.3 \\
\hline Vietnam & 20 & 2 & 3 & 2.3 \\
\hline Rest of ASEAN & 20 & 2 & 3 & 2.3 \\
\hline India & 14.66 & 1.47 & 2.2 & 2.3 \\
\hline Australia & 0 & 0 & 0 & 0 \\
\hline New Zealand & 0 & 0 & 0 & 0 \\
\hline USA & 0 & 0 & 0 & 0 \\
\hline Canada & 0 & 0 & 0 & 0 \\
\hline Mexico & 1.65 & 0.16 & 0.25 & 2.3 \\
\hline Chile & 1.63 & 0.16 & 0.24 & 2.3 \\
\hline Peru & 4.26 & 0.43 & 0.64 & 2.3 \\
\hline Russia & 1.76 & 0.18 & 0.26 & 2.3 \\
\hline EU28 & 0 & 0 & 0 & 0 \\
\hline ROW & 4.74 & 0.47 & 0.71 & 2.3 \\
\hline
\end{tabular}

* Average \% rise in real capital costs in different sectors

** Average \% rise in real labour costs in different sectors

*** Average \% rise in productivity owing to replacement of vintage capital resulting from adoption to standards 
costs of compliance to these standards for less polluting industries across the world. The costs range between 0 and 3\% of real costs of capital (Table 4). Sixth, for IP regime compliance, capital costs ranging between 0 and $2 \%$, again inversely related to per-capita income, are imposed. The results are summarized in Table 4. For both these aspects, the assumptions are supported by evidence discussed in Narayanan et al. (2016).

Seventh, as summarized in Table 4 the rise in productivity due to replacement of vintage capital is derived from the results for Japan shown by Hagiwara and Matsubayashi (2014), using the data from 1980 to 2007. This study highlights two main results of relevance for Japan-this productivity effect has been $0.15 \%$ per year and the total replacement-induced productivity from 1980 to 2007 was more than twice the real GDP growth in this period. We assume the former to hold for the developing countries in this study. We make this assumption mainly due to lack of data availability and we acknowledge this is a limitation; however, since the capital replacement and productivity related to it are a very specific technical phenomenon that may not necessarily vary across countries, particularly given that Japan grew from a poorer country to a rich one, much like the countries in our model, this is not a completely flawed assumption. Thus, even though developing countries grow, as is the case with Japan, it is natural that the quality and composition of capital goods vary across countries. As a result, the relationship between capital formation and productivity growth also varies across countries.

Eighth, for modelling the expansion in market access due to compliance with standards, the assumption is that $20 \%$ of all the disadvantages created in terms of prices will be recovered by improved market access. Without the compliance, these countries would have had no market access; we assume that such a disadvantage is partly removed by complying with these standards. The basis for the degree of this assumption is drawn from Narayanan et al. (2016).

While many of our shocks do not directly affect investment, unlike the negotiations in TTIP, for example, there are strong indirect effects on investment. Firstly, as mentioned before, movements in trade due to reduction in trade costs can actually also move investment around, to preserve the balance of payments condition. Secondly, we have shocks to capital costs in the model, which have direct bearing on investment, through the increasing or decreasing capital costs that trigger demand for capital and hence growth in investment.

\subsection{Methodological limitations}

While the GDyn model is quite robust, a few caveats as regards the data used for the analysis as well as in respect of the simulations are highlighted.

First, a large number of provisions under negotiation in the TTIP and TPP overlap with the TFA. While we reduce the NTBs by the time cost of border transit, this may not entirely capture the NTB reducing effect of the TFA. Accordingly, our policy shock for goods NTBs might overstate the remaining room for NTB reduction under TPP/TTIP. ${ }^{7}$

Second, both TPP and the TTIP measures addressing FDI are understood to be major aspects of those negotiations. While our model does capture investment dynamics

\footnotetext{
${ }^{7}$ A related caveat pertains to the timing of implementation of the TFA versus the TPP/TTIP. This is unknowable and we have assumed full implementation of all three as of 2015 for convenience. This may affect which Agreement actually would be the first mover and thus could claim credit for particular impacts.
} 
across the world quite rigorously, we do not explicitly incorporate policies and responses of FDI in detail.

Third, the shock on services' NTBs is based on ad valorem equivalents estimated by Lee and Itakura (2014); these shocks are substantially greater than has been realized in past FTAs (see Narayanan et al. 2016) concerning the discrepancy between services NTB shock estimated in conventional fashion versus based on exact coding of the legal text of the Canada-Korea FTA against the OECD's Services Trade Restrictiveness Index (STRI) as well as the provisions in Canada-Korea Free Trade Agreement. Similar reservations would hold for the NTBs in goods sectors as well. Therefore, our results in these aspects should be considered more in terms of insights and qualitatively in direction, rather than in terms of exact numbers.

Fourth, we do not explicitly take into account the utilization of preferences or the costs of utilizing preferences. Utilization of preferences involved in goods trade is rather low, especially for the exporters from developing countries. This has been illustrated, for example, in Mimouni et al. (2014). There are several reasons behind this, such as lack of awareness among the exporters, high costs of certification and compliance to meet the preferences, and rules of origin. Data on utilization employed by Mimouni et al. (2014) stand on a comprehensive transaction-level dataset on exports to certain parts of the world, mainly EU and USA. But, we could not incorporate this into our study, since this is needed for other countries as well to yield meaningful results. Thus, again, by not accounting for these costs of utilization, we are overestimating the economic impacts of these trade Agreements.

Fifth, our model and dataset do not have the linkages to fully capture the impact of increased protection for IP. In principle, increased IPRs create rents for producers, which in turn induce innovation and investment. The required market structure to capture increased rents is that of imperfect competition which includes markups; this mechanism is not, however, available in the GDyn model, nor is an innovation module that would translate increases in rents for IPR-protected firms into investment in R\&D. Since the benefit of increased R\&D would likely flow primarily to the leading R\&D centres (the USA, the EU and Japan), the absence of this linkage for purposes of our study of spillovers on India is relatively limited.

Sixth, we do not deal with liberalization of public procurement. This is of limited consequence since it is well established that most procurement is done through local presence in procurement markets. Despite this fact, we do acknowledge that the aspects of public procurement, if any, that are part of these Agreements, are not considered in this study, and to that extent, the results related to the public sector-related aspects may carry some limitations.

Finally, sensitivity tests of the results to different baselines are conducted. In general, non-TTIP/non-TPP countries and most of the smaller economies in the TPP countries have higher growth rates in the base case. While this could be the most plausible view of the world in future, it is essential to test the robustness of our results to the baseline assumption; for this purpose, we consider two alternative worldviews. One entails assuming a faster-growing set of economies in TPP and TTIP partners, while the second one involves assuming faster-growing non-TPP/non-TTIP countries. Since we found the 
results to be broadly in line with the ones shown in this study, we do not show them herein.

All these observations strengthen our view that the results from this analysis must be seen as an upper bound of what could happen in reality had TPP went ahead, and TTIP may progress.

\section{Results}

The simulations shed light on several variables and policies, and focus on two broad aspects. First, these look at the average annual impact on production of sugar across countries from 2015 to 2030 . Table 5 shows that sugar consumption is often positively affected both by raising standards and reducing tariffs in developed countries, while sugar consumption in developing countries is adversely affected.

The net global effect turns out to be around $0.3 \%$ per annum, which is a notable rise in sugar consumption globally. World Health Organization (WHO) estimates (2015) show that worldwide, many populations consume sugars at levels that exceed the WHO's sugar guideline, such as Brazil, Canada, South Africa, the UK and the USA. Sugar

Table 5 Average annual impact of TPP and TTIP on sugar consumption in \% terms (20152030)

\begin{tabular}{|c|c|c|c|c|c|c|c|c|c|}
\hline Region & $\begin{array}{l}\text { TPP } \\
\text { Tariffs }\end{array}$ & $\begin{array}{l}\text { TTIP } \\
\text { Tariffs }\end{array}$ & $\begin{array}{l}\text { Services } \\
\text { NTBs }\end{array}$ & $\begin{array}{l}\text { Labour } \\
\text { stand- } \\
\text { ards }\end{array}$ & $\begin{array}{l}\text { Environ- } \\
\text { mental } \\
\text { standards }\end{array}$ & IP rules & $\begin{array}{l}\text { Improved } \\
\text { access }\end{array}$ & $\begin{array}{l}\text { Productiv- } \\
\text { ity } \\
\text { effects }\end{array}$ & $\begin{array}{l}\text { Total } \\
\text { effect }\end{array}$ \\
\hline Japan & -0.4 & 0.2 & 0.1 & 0.3 & 0.2 & 0.1 & 0 & 0.1 & 0.6 \\
\hline China & -0.3 & -0.3 & -0.3 & -0.8 & -0.3 & -0.2 & 0.3 & 0.4 & -1.5 \\
\hline Korea & -0.1 & 0.1 & 0.1 & 0.3 & 0.1 & 0.1 & 0 & 0.1 & 0.7 \\
\hline Taiwan & -0.1 & -0.1 & -0.1 & 0 & -0.1 & 0 & 0.1 & -0.1 & -0.4 \\
\hline $\begin{array}{l}\text { Singa- } \\
\text { pore }\end{array}$ & 0 & 0.1 & 0.1 & 0.3 & 0.1 & 0.1 & -0.1 & 0.1 & 0.7 \\
\hline Indonesia & -0.2 & -0.1 & -0.2 & -0.6 & -0.1 & -0.1 & 0.1 & 0.3 & -0.9 \\
\hline Malaysia & 0.1 & 0.1 & 0.1 & 0.3 & 0.1 & 0.1 & -0.1 & 0.5 & 1.2 \\
\hline $\begin{array}{l}\text { Philip- } \\
\text { pines }\end{array}$ & -0.2 & -0.1 & -0.1 & -0.5 & -0.1 & -0.1 & 0.1 & 0.2 & -0.8 \\
\hline Thailand & -0.3 & -0.1 & -0.1 & -0.2 & -0.1 & 0 & 0.1 & 0.3 & -0.4 \\
\hline Vietnam & 0.3 & 0 & 0.1 & -0.8 & 0 & 0 & -0.1 & 0.3 & -0.2 \\
\hline $\begin{array}{l}\text { Rest of } \\
\text { ASEAN }\end{array}$ & 0 & 0 & -0.1 & 0.3 & 0 & 0 & 0 & 0.3 & 0.5 \\
\hline India & -0.1 & -0.1 & -0.1 & -0.9 & -0.1 & -0.1 & 0.1 & 0.3 & -1 \\
\hline Australia & 1 & 0.1 & 0.3 & 0.3 & 0.1 & 0.1 & 0.1 & 0 & 2 \\
\hline $\begin{array}{l}\text { New Zea- } \\
\text { land }\end{array}$ & 0.2 & 0.1 & 0.2 & 0.1 & 0.1 & 0.1 & 0 & 0.1 & 0.9 \\
\hline USA & 0 & 0.2 & 0.2 & 0.3 & 0.2 & 0.1 & 0 & 0.1 & 1.1 \\
\hline Canada & 0.3 & 0.1 & 0.1 & 0.3 & 0.1 & 0.1 & 0 & 0.1 & 1.1 \\
\hline Mexico & 0.3 & 0 & 0 & -0.1 & 0 & 0 & 0 & 0.2 & 0.4 \\
\hline Chile & 0.1 & 0 & 0 & 0.1 & 0 & 0 & 0 & 0.4 & 0.6 \\
\hline Peru & 0.3 & 0.1 & 0.1 & -0.1 & 0.1 & 0 & 0 & 0.4 & 0.9 \\
\hline Russia & 0 & 0 & 0 & 0 & 0 & 0 & 0 & 0.3 & 0.3 \\
\hline EU28 & 0.1 & 0 & 0.1 & 0.1 & 0.2 & 0 & 0 & 0.1 & 0.5 \\
\hline ROW & 0.2 & 0.0 & -0.1 & -0.1 & 0.0 & 0.0 & 0.1 & 0.2 & 0.1 \\
\hline Average & 0.0 & 0.0 & 0.0 & -0.1 & 0.0 & 0.0 & 0.0 & 0.2 & 0.3 \\
\hline
\end{tabular}


consumption is growing, especially in low- and middle-income countries. Between 2000-2001 and 2013-2014, global sugar consumption grew from about 130-178 million tonnes and is expected to reach about 182 million tonnes in 2014-2015. Almost three quarters of global sugar consumption each year takes place in developing countries. This overconsumption of sugar is taking place in the context of a cheap and abundant supply of sugar on the world market, which can be attributed to lowering/elimination of tariffs on sugar and sugary products that are likely to boost sugar consumption. The WHO (2014) draft guideline on sugars intake proposed that sugars should be $<10 \%$ of total energy intake per day. But tariff reduction on sugar will have the opposite effect on public health.

Second, as given in Table 6, stricter IP rules have a net positive effect globally in terms of employment and GDP and a net negative effect in terms of investment. Thus, new competing investment that could improve access to medicine may be hindered by these rules, and even apart from this, we note that poorer countries are adversely affected by stricter IP rules.

TRIPS-plus-style commitments under mega-regionals allow transition periods for developing countries. But these also allow rights and privileges to foreign investors, with the obligation on governments to provide protection of such rights. Such obligations can significantly restrict a government's ability to regulate how companies operate within its national borders, which may then have an impact on the promotion of access

Table 6 Impact of strict IP rules on changes in employment, GDP and investment

\begin{tabular}{lccccc}
\hline Region & $\begin{array}{l}\text { Unskilled } \\
\text { employment } \\
\text { (in \% terms) }\end{array}$ & $\begin{array}{l}\text { Skilled } \\
\text { employment } \\
\text { (in \% terms) }\end{array}$ & $\begin{array}{l}\text { GDP } \\
\text { (in \% terms) }\end{array}$ & $\begin{array}{l}\text { GDP (value } \\
\text { terms-change } \\
\text { in \$ millions) }\end{array}$ & $\begin{array}{c}\text { Investment } \\
\text { (in \% terms) }\end{array}$ \\
\hline Japan & 0.11 & 0.15 & 0.16 & 6834.61 & 0.33 \\
China & -0.07 & -0.09 & -0.31 & $-18,787$ & -0.52 \\
Korea & 0.09 & 0.13 & 0.12 & 1302.97 & 0.27 \\
Taiwan & -0.05 & -0.05 & -0.13 & -547.56 & -0.18 \\
Singapore & -0.01 & -0.01 & -0.02 & -38.39 & -0.04 \\
Indonesia & -0.03 & -0.05 & -0.21 & -1463.4 & -0.19 \\
Malaysia & 0 & 0.01 & -0.05 & -140.37 & -0.07 \\
Philippines & -0.05 & -0.07 & -0.2 & -375.53 & -0.31 \\
Thailand & -0.01 & -0.02 & -0.08 & -254.15 & -0.15 \\
Vietnam & 0.03 & 0.05 & 0 & -2.49 & 0.05 \\
Rest of ASEAN & 0.01 & 0.09 & -0.04 & -39.43 & 0.02 \\
India & -0.07 & -0.09 & -0.3 & -5206 & -0.48 \\
Australia & 0.01 & 0.01 & 0.01 & 104.77 & -0.02 \\
New Zealand & 0.06 & 0.07 & 0.08 & 139.08 & 0.1 \\
USA & 0.1 & 0.12 & 0.13 & $16,865.3$ & 0.22 \\
Canada & 0.07 & 0.07 & 0.08 & 1446.44 & 0.11 \\
Mexico & -0.01 & -0.02 & -0.05 & -665.77 & -0.02 \\
Chile & 0.05 & 0.05 & 0.01 & 28.71 & 0.09 \\
Peru & 0.05 & 0.04 & 0.04 & 58.43 & 0.01 \\
Russia & 0.02 & 0.03 & 0 & 41 & 0.23 \\
EU28 & 0.09 & 0.12 & 0.13 & $17,993.4$ & 0.33 \\
ROW & -0.02 & -0.03 & -0.07 & $-10,424$ & -0.07 \\
Average & 0.01 & 0.01 & 0.01 & 312.3 & 0.01 \\
\hline & & & & & \\
\hline
\end{tabular}


to medicines and the protection of public health in general. In this manner, the potential impact on public health of the deep provisions on investment highlights three areas of concern. First, the expansive rights and privileges accorded foreign investors, with the corresponding obligation on governments to provide protection of such rights is likely to have the effect of significantly restricting governments' ability to regulate how companies operate within their national borders. Current disputes in tobacco regulation demonstrate the potential public health implications that may arise from broad definitions of "investment" and the obligation to protect investors and their investments. Second, the investment provisions combine strong investors' rights and high protection standards with a dispute settlement mechanism (the ISDS), which would provide the "teeth" for enforcement of those obligations. It is also noted that IP rights are included in the definition of "investment", which would mean that a government measure affecting the intellectual property holdings of investors may be considered an "expropriation" or the withholding of "fair and equitable treatment". This raises concern about the ability of governments to implement and use the range of TRIPS flexibilities, many of which could be seen as limitations or restrictions of the exclusive rights granted under a patent. Although the proposals provide that compulsory licensing does not constitute an expropriation where such a licence is granted "in accordance with the TRIPS Agreement", this still leaves room for investor corporations to challenge the compulsory licence using the ISDS on the grounds that it does not comply with TRIPS. A related concern is that the extensive investor rights and the ISDS framework might provide a legal framework by which corporations may challenge any government measure, thus engendering a "chilling effect" on government regulation and action.

\section{Conclusions and policy implications}

The TPP Agreement and proposed TTIP go well beyond traditional trade concerns and includes, among other elements, extensive obligations related to IP and investor protection. In fact, the health concerns with the TPP arise from the intensification of existing trade provisions and unprecedented protections for investors and intellectual property right holders. The analysis of commitments and modelling exercise support the view that the mega-regional Agreements are likely to have major implications for public health and access to medicines. The IP obligations under TPP exceeded the minimum standards of the multilateral WTO Agreement on TRIPS. The potential health effects of TPP and TTIP cannot be ignored and need the attention of negotiators, not merely because of the adversity in terms of health, but also due to the magnitude of overall economic effect. While the promotion of free trade via tariff elimination and economic growth is important, it must be balanced against the need to ensure both a population's access to needed medicines and its long-term health and well-being. While the annulment of TPP or putting the TTIP on hold has not been done with the potential impacts in mind, it is important that policy-makers are wary of the effect of the mega-regionals and how these can translate into gains for countries in the public health domain. This is due to the fact that the simulation results suggest an increase in sugar production that is a silent killer in terms of being a contributor of obesity and diabetes. Further, if countries adopt TRIPS-plus provisions this is likely to threaten access to pharmaceuticals for people in developing countries, which points in the direction that the negotiating countries may 
wish to consider the types of measures that would strengthen and further expand the gains made in the effort to increase treatment access.

Another important implication is that the importance of relationship between IP rights and competition law cannot be understated. While IP protection effectively vests exclusive control of production and supply of protected invention in the rights holder, competition law seeks to encourage a multiplicity of suppliers in order to ensure effective competition in the market place. In most developed countries, higher standards of IP protection have evolved alongside the development of norms providing effective defence against anti-competitive practices related to the acquisition and exercise of IP rights. The policy objective from the perspective of developed countries is, therefore, to achieve a balance between intellectual property rights and competition that is appropriate to the domestic context. But this represents a complex challenge in developing countries given most lack competition law framework and/or effective mechanism for implementation of anti-competitive practices. Despite such practical concerns, most developing countries have undertaken deep intellectual property rights commitments as well as expanded existing ones without the capacity to implement, which is a matter for thought.

The empirical information made available by this paper can serve a variety of purposes. First and foremost, it provides a basis of evidence to inform policy-makers and strengthen their position in trade negotiations. The information can help to identify those areas in which greater flexibility in the negotiation of new IP standards may be warranted, or can make the case that new standards may not be desirable at all. Further, in countries that have adopted TRIPS-plus standards as under TPP, the evidence can provide an important basis from which to identify complementary policies that can remedy or alleviate the negative impacts of implementation.

In this light, governments may wish to adopt coherent approaches, in which trade and IP policies are formulated in a manner that preserves developing countries' ability to provide long-term, affordable and sustainable access to medicines. While the current state of annulling the TTP talks and uncertainty around TTIP are not attributed to these concerns, ongoing mega-regional (and bilateral) negotiations must bear these policy aspects in mind. It is, thus, imperative that governments adopt a "positive agenda", wherein they actively identify and implement policies that can help achieve the goals of trade and economic growth, alongside the objectives of ensuring access to needed medicines and the protection of public health. This leaves the question unanswered whether commitments under mega-regional Agreements addressing trade issues and twentyfirst-century challenges are next-generation regional Agreements, and if such commitments are likely to impact on policy space of developing countries.

Authors' contributions

BN conceived, designed and implemented the simulations and prepared the manuscript. SK prepared the manuscript, explained some of the results in the model and pursued literature review. Both authors read and approved the final manuscript.

Author details

${ }^{1}$ University of Washington Seattle, 21746 SE 3rd PL, Sammamish, WA 98074, USA. ${ }^{2}$ Bournemouth University, Poole, UK. 
Competing interests

The authors declare that they have no competing interests.

Availability of data and materials

Data used for the study have been summarized in the paper. More details may be shared with readers individually upon request.

\section{Consent for publication}

We hereby provide our full consent to publish this paper in this journal.

\section{Ethics approval and consent to participate}

Not applicable.

\section{Funding}

We gratefully acknowledge research funding from Bournemouth University for this paper.

\section{Publisher's Note}

Springer Nature remains neutral with regard to jurisdictional claims in published maps and institutional affiliations.

Received: 22 March 2017 Accepted: 12 October 2017

Published online: 30 October 2017

\section{References}

Brown DK, Kiyota K, Stern RM (2010) Computational analysis of the menu of US-Japan trade policies. RSIE discussion paper no. 611, Ford School of Public Policy, University of Michigan

Chappius T, Walmsley T (2011) Projections for world CGE model baselines. GTAP Research Memorandum No: 22. September. The Center for Global Trade Analysis, Purdue University, West Lafayette, USA

Clarke M (2008) Vulnerability, prevention and human trafficking: the need for a new paradigm: anintroduction to human trafficking: Vulnerability, impact and action, UN Organization on Drugs and Crime,Vienna

Clark SE, Hawkes C, Murphy SME, Hansen-Kuhn KA, Wallinga D (2012) Exporting obesity: US farm and trade policy and the transformation of the Mexican consumer food environment. Int J Occup Environ Health 18:53-64

Ciuriak D, Jingliang X (2014) The trans-pacific partnership: evaluating the 'Landing Zone' fornegotiations. Working Paper

DeRosa DA, Gilbert JP (2004) Technical Appendix: Quantitative Estimates of the EconomicImpacts of US Bilateral Free Trade Agreements. In: Jeffrey JS (ed) Free Trade Agreements: U.S. Strategies and Priorities, Washington, D.C, Institute for International Economics

Drahos P (2003) Access to medicines: after doha. In: Grynberg R, Turner E (eds) multilateral and regional trade issues for developingcountries. Commonwealth Secretariat, London

El-said M (2010) Public health related TRIPS-Plus provisions in bilateral trade agreements: a policyguide for negotiations and implementers in the eastern mediterranean region'. In: World Health Organization(WHO) and the International Centre for Trade and Sustainable Development (ICTSD)

Foure J, Benassy-Quere A, Fontagne L (2010) The world economy in 2050: a tentative picture. CEPII working paper 201027, CEPII, Paris, France

Gaisford JD, Hobbs JE, Kerr WA (2007) Will the TRIPS Agreement foster appropriate biotechnologies for developing countries? J Agric Econ 58(2):199-217

Hagiwara T, Matsubayashi Y (2014) Capital accumulation, vintage and productivity: the Japanese experience. Discussion paper no. 1418, Graduate School of Economics, Kobe University. Available online at http://www.econ.kobe-u.ac.jp/ RePEc/koe/wpaper/2014/1418.pdf

Hummels D, Minor P (2009) Time as a barrier to trade: a GTAP database of ad valorem trade timecosts (Paper presented at the 13th Annual Conference on Global Economic Analysis, Penang, Malaysia

lanchovichina E, McDougall R (2001) "Structure of Dynamic GTAP." GTAP Technical Paper 17, Centerfor Global Trade Analysis, available on line athttp://www.gtap.org

lanchovichina E, Walmsley T (eds) (2012) Dynamic modeling and applications for global economic analysis. Cambridge University Press, Cambridge

lanchovichina E, Hertel T, Walmsley T (2014) Projections for world CGE model baselines. GTAP Research Memorandum no. 26 February, The Center for Global Trade Analysis, Purdue University, West Lafayette, USA

Kee HL, Nicita A, Olarreaga M (2009) Estimating trade restrictiveness indices. Economic Journal 119:172-199

Kerr WA (2003) The efficacy of TRIPS: incentives, capacity and threats. Estey Centre J Int Law Trade Policy 4(1):1-14

Kerr WA (2005) Agriculture: a key to the WTO Doha Development Agenda. In: Proceedings of an Asian Development Bank high level meeting on WTO Key Doha Round issues, Osaka, Japan, 3-5 Aug

Kerr WA (2007) Trade related aspects of intellectual property: enforcement issues. In: Kerr WA, Gaisford JD (eds) Handbook on international trade policy. Edward Elgar, Cheltenham, pp 520-526

Kerr WA (2011) Conflict, chaos and confusion: the crisis in the international trading system. Edward Elgar, Cheltenham Lee H, Itakura K (2015) The implications of region-wide FTAs for Japan and emerging Asia, Osaka School of International Public Policy (OSIPP) Discussion paper no. 2015-E-001, March 31, 2015, available online at http://www.osipp.osaka-u. ac.jp/archives/DP/2015/DP2015E001.pdf. Assessed on 2 Mar 2017

Lee H, Itakura K (2014) TPP RCEP and Japan's agricultural policy reforms. OSIPP DiscussionPaper, Osaka School of International Public Policy, Osaka 
Mimouni M, Pichot X, Narayanan B (2014) Utilization of preferential tariffs. Paper presented at 2014 conference of global economic analysis, Dakar, Senegal. Abstract available online at https://www.gtap.agecon.purdue.edu/resources/ res_display.asp?RecordID=4458. Assessed on 2 Mar 2017

Minor P, Hummels D (2011) Time as a barrier to trade: a GTAP database of ad valorem trade time costs. Paper presented at 13th annual conference on global economic analysis, Penang, Malaysia. Available online at L: https://www.gtap. agecon.purdue.edu/resources/res_display.asp?RecordID=3301. Assessed on 2 Mar 2017

Narayanan BG, Aguiar A, McDougall R (eds) (2012) Global trade, assistance, and production: the GTAP 8 data base. Center for Global Trade Analysis, Purdue University, West Lafayette. Available online at: https://www.gtap.agecon.purdue. edu/databases/v8/v8_doco.asp. Assessed on 2 Mar 2017

Narayanan GB, Ciuriak D, Singh HV (2016) Quantifying trans-Pacific partnership and transatlantictrade and investment partnership spillovers on India. Chapter 4 in ed. HV Singh. TPP and India. WisdomTree Publishers, India.

Reichenmiller P (2005) Tightening TRIPS: the intellectual property provisions of recent US free trade Agreements. World Bank, Washington, DC. Trade Note no. 20. Online access: http://siteresources.worldbank.org/INTRANETTRADE/ Resources/Pubs/TradeNote20.pdf. Assessed on 2 March 2017

Roffe P, Von Braun J, Vivas-Eugui D (2008) A new generation of regional and bilateral trade Agreements: lessons from the US-CAFTA-DR Agreement. In: Blouin C, Drager N, Heymann J (eds) Trade and health: seeking common ground. McGill-Queen's University Press, Montréal, pp 41-89

Vivas-Eugui D (2003) Regional and bilateral Agreements and a TRIPS-plus world: the Free Trade Area of the Americas (FTAA), TRIPS issues papers no. 1, Geneva

Walmsley Terry, Hertel Thomas, lanchovichina E (2006) Assessing the impact of China's WTO accession on investment. Pac Econ Rev 11(3):315-319

Wang Z, Mohan S, Rosen D (2009) Methodology for estimating services trade barriers. Rhodium Group and Peterson Institute for International Economics

World Health Organisation (WHO) (2014) Draft sugars consultation children and adults http://www.who.int/mediacentre/news/notes/2014/consultation-sugar-guideline/en/. Assessed on 2 Mar 2017

World Health Organisation (WHO) (2015) Guideline: sugars intake for adults and children. World Health Organization, Geneva

\section{Submit your manuscript to a SpringerOpen ${ }^{\circ}$ journal and benefit from:}

- Convenient online submission

- Rigorous peer review

- Open access: articles freely available online

- High visibility within the field

Retaining the copyright to your article

Submit your next manuscript at $\boldsymbol{\nabla}$ springeropen.com 